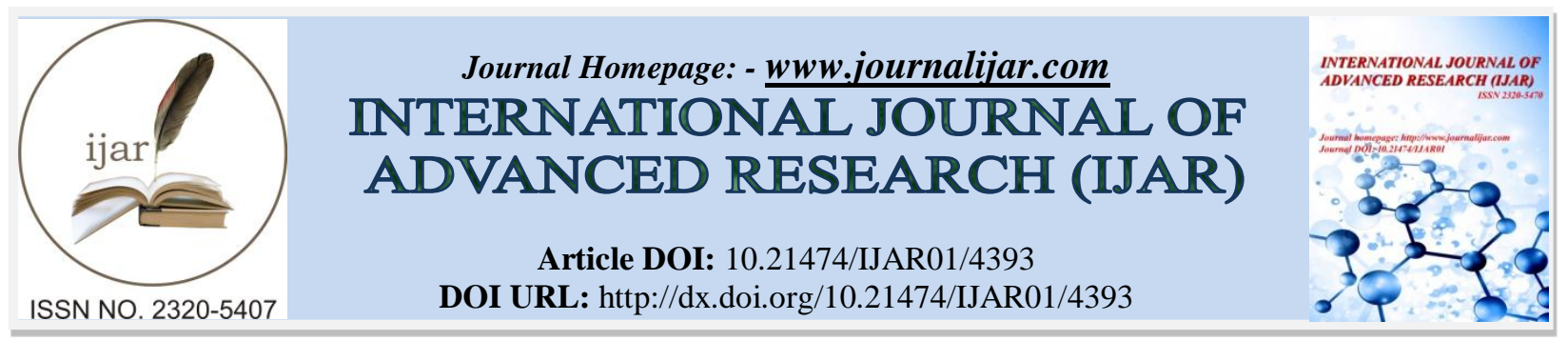

RESEARCH ARTICLE

\title{
THE IMPLEMENTATION OF THE ACT OF MILITARY CIVIC ACTION FOR VILLAGES DEVELOPMENT IN ORDER CREATE THE AWARENESS OF NATIONAL DEFENSE.
}

Edward Gildas Abraham, Zaenal Fanani and Mukhammad Soleh.

Research Study of the Implementation of the Indonesia Army (TNI) Civic Action for developing the Sub-District of Bantur, Malang Regency, Indonesia.

\section{Manuscript Info}

(........................

Manuscript History

Received: 04 april 2017

Final Accepted: 06 june 2017

Published: june 2017

Key words:-

analysis, implementation, discrepancy, national defense, security defense.

\section{Abstract}

The goal of this research is to learn and evaluate the effectiveness of the implementation of the act of TNI civic action to build villages (TMMD) in order to create the awareness of national defense in the attempt of increasing the endurance of the defense and security in the Sub-District of Bantur, Malang Regency. This research uses the qualitative method with the discrepancy evaluation method. The data are collected through interview, observation, questionnaire, group discussion and documentation study. The result of this research shows that the act TMMD of 2014 in Sub-District of Bantur, Malang Regency through the physical and non-physical activities in order to create the awareness of national defense in attempt to increase the endurance of the defense and security is not effective and efficient yet.

Copy Right, IJAR, 2017,. All rights reserved.

\section{Introduction:-}

In term of protecting the unity and the sovereignty of Indonesia, the government in the aspect of defense has issued the policies about the strategy of defense of the nation. The policy mentioned in the White Book of the Defense of Indonesia (Ministry of Defense of Indonesia of 2015) has clearly emphasized about the strategic target of the national defense that will be the goal, one of those is "creating a society with the awareness of national defense". Creating the society with the awareness of defending the nation as one of the strategic goals of the nation defense is very relevant and actual if faced with the phenomena of life of the people as a nation and a state nowadays. This can be seen from the establishment of the construction of the defense until the recent time is not yet able to create a strong figure of defense feared by the world, even in the regional scope Indonesian defense is not yet seen as the strongest.

In several recent years, the national building is still putting the aspect of prosperity as the priority that causing the decreasing of speed and the limitation upon the modernization of the defense. The real condition of Indonesia like mentioned above has the implication upon the practice of the building in the sector of defense of the Nation that until now is not yet to achieve the standard of prevention that is expected, even is under the minimum defense power. (Department of Defense of Indonesia 2007). In the limited building of the posture and the structure of Indonesian Military (TNI), then the support of the people becomes crucial and relevant in the condition faced by the state and Nation here in order to achieve the strategic goal of the national defense especially "creating the people with awareness of national defense". 
Pointing on the awareness of national defense as one of the strategic goals of the national defense that has been long established with various activities including the program of TNI civic action to develop villages (TMMD) supposed to already become steady such as the increasing of the awareness of the society in the life as a nation and state. Including the growing of the spirit of togetherness, mutual cooperation and the feeling of fraternity. As well as the active participation of the society in building their region and the established of the strong soul of unity (Mabesad, 2009). Yet the question arose is how far have we achieved the "society with the awareness of national defense" recently?

In order to know how far the success of the achievement of the awareness of national defense as one of the strategic targets of the national defense and also as one of the goal of the program of TMMD. Hence, it needs to have certain analysis upon the implementation of the activity of TMMD especially in Sub-District of Bantur, Malang Regency. According to Weimer and Vining (1989) in the quotation of Widjajono Partowidagdo (2010), analysis derived from Greek word that means "becomes the components. Then, according to Robert J. Schreiter (1991) mentioned that analysis is reading text by putting the marks in the dynamic interaction and the messages delivered. Analysis according to "Kamus Lengkap Bahasa Indonesia" (Em Zul Fajri \& Ratu Aprilia Senja) is a process of searching the resolution that departs from the assumption upon truth; the investigation towards an occurrence to find out the real situation.

The data of the activity gathered then will be evaluated with the discrepancy model to find out whether the activity done has already accurate with what is expected or not. If the data of the actual activity is not accurate with what expected that discrepancy happened. This discrepancy evaluation model is developed by Malcolm Provus (Arikunto and Safruddin, 2008). Hence, the analysis and evaluation upon the implementation of TMMD needs to be done in order to find out how far the success of the effort of creating the awareness of national defense of the society in SubDistrict of Bantur, Malang Regency where this empirical information will be the input upon the decision making of the improvement.

\section{Methodology:-}

In accordance to Finlay (2006) that qualitative research is a research based on the concept of "going exploring" that involves in-depth and case-oriented study of several cases or single case. Referring to the method of research developed by Creswell that qualitative research is classified in five types; those are ethnography, grounded theory, case study, phenomenology, narrative. In this research, case study is used. Principally, the analysis of the case study carefully investigates an activity from the society or a group of individual. The cases are limited by the time and activity setting and the researcher collect complete information by using various procedure of data collecting. The type of data needed are; (1) the activity of TMMD of 2014 in Sub-District of Bantur, Malang Regency, the physical and the non-physical ones, (2) values of national defense contained in the TMMD of 2014 in Sub-District of Bantur, Malang Regency, (3) the hindrances faced in TMMD mentioned. These data gained from the interviews (primary data) as well as scientific documents (secondary data) including: guidebook, rule of constitution, reference book, result of previous research (thesis, journal, report), article as well as news related published in mass media.

\section{Discussion:-}

The object of this research is the actualization of national defense in distinguishing which the source and which the object of the research based on the activity of TMMD done in 2014 in Sub-District of Bantur, Malang Regency.

\section{The Conception of National Defense:-}

The word of national defense derived from self-defense which means "the use of force to protect yourself against someone who is attacking you" (Collins Cobuild, 2001:1404) so that it can be interpreted as an act to defend from the attack of the opponents. While self-help as mentioned above is an attempt done by the country to defend its own country. Since the act is done by the subject of the country collectively the object protected is the country and all within, then the term of "self-defense" can be expanded into "national defense" (Saeful Anwar, 2016:65).

National defense, according Marsono (2015:39) is the basic duty of human, it is also the honor for every society who has the full awareness, responsibility, and willing to fight for the nation and the state. National defense for the society of Indonesia can be interpreted as the attitude and behavior of the society that is done from the spirit of the loving to Country of Indonesia (NKRI) based on the Pancasila and the Constitution of 1945 in gaining the continuity of life of the nation and the state fully. The meaning of national defense is the Society of Indonesia (WNI) that has 
the will, attitude and behavior that is done from the spirit of the loving to Country of Indonesia and the Constitution of 1945 that willing fight for the sake of the continuity of the nation and the state. While the criteria of the society that has the awareness of national defense are those who have the attitude and act in accordance to the values of the national defense.

The term of national defense can be found in the formulation of Article 27 point 3 of the Constitution of NRI 1945. Article 27 point 3 mentioned "Every society has the right and must participate in the attempt of national defense". In the book of "Pemasyarakatan" of Constitution of Indonesia of 1945 by the MPR (2012) explained that Article 27 point 3 here means to strengthen the concept that believed by the nation and the state Indonesia in term of national defense, that is the attempt of national defense. Moreover, that it is not only the monopoly of the TNI, yet is a right as well as the obligation of all the society. Each of the society can participate in every effort of national defense according to their own capability and profession. (Kemensristekdikti of Indonesia 2016:249)

To find out the degree of success of the teaching of the defending of the national, it needs the presence of indicators. While the indicator of willing to fight for the nation and the state, is reflected in the attitude and behavior such as: (1) The willingness to help others, no matter what is their background of the socio-cultural. (2) Prioritizing the urges of the public rather than personal needs. (3) Willing to contribute in term of energy, thoughts, ability and skill as well as the material for the sake of the society, nation and state. (4) Ready to defend the nation and the state from various types of threat. (5) Have faith and believe that the sacrifice for the nation and the state is not wasted. While the indicators of loving the nation, is reflected in the attitude and behavior such as: (1) loving the local products. (2) Diligently studying for the sake of the nation and the state. (3) Loving the environment. (4) Able to do the healthy living. (5) Know the territories of the nations without the sense of the regional fanatics (Kemenhan of Indonesia, 2014).

\section{The Conception TNI civic action to build villages (TMMD):-}

TMMD is one of the coordinated program across the sectoral of TNI, Governmental Ministry/Non-Governmental Agency and the Regional Government as well as the other components of the nation. In which is done integrated along with the society in order to increase the acceleration of the activity of regional building in village area especially the region that classified as left behind/poor, isolated/remote, the borderline and the slum area of the city as well as the other region that damaged by the natural disaster. The goal of the TMMD by the TNI here is to create the Fighting Room, Fighting Tool, Fighting Condition and the Integrity of TNI-Society. That is done also in order to help the Government in increasing the prosperity of the people through the building that is physical and nonphysical in creating a conducive situation for the achieving of the stability of the security in the nation. One of the goals of the TMMD program is the more increased the knowledge of nationality as well as the awareness upon national defense reflected in the pattern and life attitude of each of the society according to the field and profession also their contribution. The kind of activities of TMMD are covering those physical and non-physical. The nonphysical activities are done to motivate the people to participate in term of the building and the awareness of national defense through various activities (Mabesad, 2009). Based on the indicator of success about the implementation of national defense through the holding of TMMD of 2014 in Sub-District of Bantur, Malang Regency is elaborated as follow.

\section{Physical Activities:-}

In implementing these activities, it indicates that there are some activities containing the values of awareness of defending country in the level of civilians. That is indicated from the creation of a governance and mechanism that is coordinated and institutionalized in the environment of Regional Government of Malang Regency and in Kodim 0818/Malang-Batu. Also, the presence of support and participation of the society that supports the program of building in its region as well as in order to prepare the Posts of Defense in the region. Then, it can also see from the success of the construction of bridge and the road as the public facilities according to the goal of achievement that made so that it will ease the transportation to the deepest village. Besides, the building of the awareness of national defense as the impact of the TMMD program is the success of the construction of pipelines and water tank in order to support the effort to achieve clean water availability for the society so that the supply of clean water can be sufficient for the daily needs of the society. Also, important, the success of the construction of the irrigation system in order to increase the productivity of agriculture since the needs of water in the rice field in Srigonco Village of Bantur Sub-District can be fulfilled. 


\section{Non-Physical Activities:-}

In the implementation of this activity, it also shows some activities that contains the values of awareness of national defense in the society through the participation of the society in the socialization of the Knowledge of Nationality to increase the level of nationalism and awareness of the society especially the youth in doing the National defense. This achievement is expected to build the fighting power of the society upon the threats that might come from the inside as well as from the outside of the region. Besides, with the activity to increase the understanding upon the ideology of Pancasila so that it can be accepted as the only ideology of the Nation. The increasing of the awareness of living as a nation and a state especially for the society through the growing of the nationalism within the society as the result of the activity of socialization of the Knowledge of Nationality also the indicator of the success in building the awareness of National Defense of the local society. Also, very important, the presence of faith in Republic Indonesia is no question and must be kept until the end of life, by living the Wisdom of Fighting of 1945 is a symbol of the occurrence of awareness of National Defense of the local society including with the participation of the society in socialization of the danger of illegal drugs. This is so that the awareness of the danger of illegal drugs for the youth is occurred. Besides, the prove that the awareness of national defense is built can be seen by the high level of participation of the children in the painting competition. This activity stimulates the mind of the children that reflect the situation that is expected and the imagination of the children about the future with the theme of the Integrity of TNI and Society will achieve an early education about the National Defense. Besides, the help of giving books in order to increase the knowledge of the children and the society through reading is expected to be able to build the awareness of national defense of the local society.

\section{Model of Activity of TMMD that is effective and efficient in order to create the national defense:-}

The TMMD model that is effective and efficient to achieve the implementation of national defense as the part of the aspects of defense in the Sub-District of Bantur, Malang Regency is a TMMD that can design and accommodate things as follow.

First, designing the activities of TMMD that is physical and the non-physical that contains the points of national defense proportionally according to the condition of the local society.

Second, the setting of goals of the activities of TMMD is ought to not be monotonous and expected to be more varied so that it has more flexibility in developing the form of activities that can create and increase the understanding and the practices of national defense for the society.

Third, increasing the number of involvement of related materials especially those that has the competence and ability of understanding the value of national defense so that it can develop activities and can reach the wider society in understanding as well as the practice of national defense of the local society.

Fourth, broaden the involvement of the society in the activity of TMMD in term of quality and quantity that gains the support of the budget that is sufficient so that the participation of the society can be maximum. Besides, it needs to anticipate and look for solution due to the behavior of the society that is hindered by their activities they do for living of their family in daily bases. With this policy, it is expected that it can increase the participation of the society in activities of understanding and the practice of national defense to become more optimal.

Fifth, the practice of support on facility and infrastructure in the activity of TMMD needs to also consider proportionally the urges of activity of the development of values in national defense so that the support of facility and infrastructure has been prepared from the beginning properly.

Sixth, although it becomes a classic problem and cliché that the support of budgeting in TMMD here is also more proportional in creating the activities either the physical and the non-physical ones that can be developed into some activities that contain the values of national defense.

Seventh, before the TMMD program is held, it needs the socialization that is intensive and broad about the TMMD programs especially about the goal and the target of the TMMD in itself far before the day it is held. Some of the ways are by activities of meeting/audience with the public figures, religious figure, as well as the cultural and the youth figure and through other mass media. 
Eighth, which is also very important, the time allocation of the TMMD needs to be developed and broadened so that the activities for the understanding and the practice of the values of national defense for the local society can be more optimal.

The similarities and the differences with the result of previous research: -

The similarities of this research with the previous research is that it is done by using the case study method by using the qualitative approach with the focus of the research is still on the implementation of the value of national defense. The difference with the previous study is on the object of the research that is the implementation of the TMMD program. In the same thing, the location of the research is also the different. In analyzing the result of the research is done with the evaluation model of discrepancy as the main theory. While the previous research used the perception concept.

\section{Conclusion:-}

Based on the result of the research upon the implementation of the TMMD program of 2014 through the activities of physical and non-physical in the Sub-District of Bantur, Malang Regency is not yet effective and efficient in order to increase the awareness of National Defense in creating a sufficient defense and security. This is shown by the presence of various hindrance in term of establishing the target of activity, human resources, facility and infrastructure, funding support, time allocation as well as dislocation of activity that affect significantly towards the activity of TMMD in creating the value of National Defense as the actualization of the defense of the nation.

\section{Suggestion:-}

To create an effective and efficient TMMD model in order to create the values of National Defense for the sake of a good security in the local Sub-District of Bantur, Malang Regency, several things are suggested.

1.1.1. Planning Aspect. Planning the activities of TMMD that are physical and non-physical that contains a proportional value of national defense according to the condition of the local society.

1.1.2. Achievement Aspect. The goals of activities in TMMD ought to be not monotonous and expected to be more varied so that it will have more flexibility in developing the forms of activities that can create and increase the understanding and practice of National Defense.

1.1.3. Aspect of External Involvement. Increase the involvement of the related stakeholders especially those that have the competence and capability of understanding the value of national defense so that it can develop the activities and reach the society broader in term of understanding as well as the practice of national defense for the local society.

1.1.4. Aspect of Society Involvement. Broaden the involvement of the society in the TMMD activities in term of quality and quantity that gain the sufficient support of budgetary so that the role of the society is more optimal. It needs to also anticipate and finding the solution of the impact of the social behavior that will hinder them to gain a living for the daily life of their family. With this policy, it is expected that TMMD can increase the participation of the society in activities of understanding and practice of national defense to become more optimal.

1.1.5. Aspect of Support of Facilities. The practice of support of budgetary in TMMD activities needs to consider proportionality of the urgency of the activities in developing the values of national defense so that the support of facilities has prepared from the beginning well.

1.1.6. Aspect of Funding Support. TMMD needs the support of funding in the activities to be more proportional in creating activities whether the physical and the non-physical that can be developed for the activity to promote National Defense values.

1.1.7. Socialization aspect. TMMD needs to have a broad, intensive socialization about the activities of the TMMD program especially the goal, and the target of the practices of the TMMD far before it is held. Some of the way to socialize are by the meeting with the public figure, religious icon, cultural icon as well as well the youth representative and also through the mass media.

1.1.8. Time Allocation and Activity Dislocation Aspect. TMMD needs to develop and broaden the time allocation and the activity dislocation so that the activities to achieve the understanding and the practice of the values of national defense for the local society can be more optimal. 


\section{References:-}

1. Arikunto, Suharsimi dan Jabar, Cepi Safruddin Abdul.2008. Evaluasi Program Pendidikan: Pedoman Teoritis Praktis Bagi Mahasiswa dan Praktisi Pendidikan. Jakarta : PT. Bumi Aksara.

2. Basuki, Ahmad Yani. 2013. Reformasi TNI: Pola, Profesionalitas dan Refungsionalisasi Militer Dalam Masyarakat. Jakarta: Pusat Pengkajian Strategi Nasional.

3. Departemen Pertahanan RI. 2007. Doktrin Pertahanan Negara.Jakarta: Departemen Pertahanan Republik Indonesia.

4. Departemen Pertahanan RI. 2007. Postur Pertahanan Negara.Jakarta: Departemen Pertahanan Republik Indonesia.

5. Fagoyinbo, Josep Babatunde. 2013. The Armed Forces: Instrument of Peace, Strenght, Development and Prosperity. Bloomington: Author House.

6. Fauzi, Gamawan. 2013. Program TNI Masuk Desa Bermanfaat bagi Masyarakat. Jakarta:

7. Hunter, Wendy. 1996. Redefining the Military's Role in Argentina, Brazil, and Chile, United States Institute Of Peace-Peaceworks No.10.

8. Mabesad. Panduan/Petunjuk Pelaksanaan TNI Manunggal Membangun Desa TA 2016. Jakarta: Penanggung Jawab Operasional TMMD TA 2014. 2014.

9. Prabowo, J.Suryo. 2013. Komando Teritorial:Sebagai bagian dari gelar kekuatan TNI AD. Jakarta:

10. Syaiful Anwar. 2016. Melindungi Negara, Jakarta: Yayasan Pustaka Obor Indonesia.

11. Mabesad. 2009. Buku Panduan Penyelenggaraan Program TMMD. Jakarta: Staf Umum Teritorial Mabesad. 